\title{
PENERAPAN MODEL PEMBELAJARAN PROJECT BASED LEARNING (PjBL) UPAYA PENINGKATAN KREATIVITAS MAHASISWA
}

\author{
Rona Taula Sari, Siska Angreni \\ Program Studi Pendidikan Guru Sekolah Dasar \\ Fakultas Keguruan dan Ilmu Pendidikan \\ Universitas Bung Hatta \\ ronataulasari@bunghatta.co.id
}

\begin{abstract}
The purpose of this study is to describe the creativity of students through the learning of Project Based Learning. The research was conducted with One-Shot Case Study design with 45 students of Fungus Elementary School Teacher Education Program of Bung Hatta University. The research data is obtained from analysis of product observation sheet with Creative Thinking Scale (CTS). Data analysis with percentage technique and processed descriptively. The result of the research shows the creativity of the students in producing the organic and inorganic waste processed handicraft product is very high with the value 92. It can be concluded that the Learning Based Learning model can improve student creativity.
\end{abstract}

Keywords: Model PjBL(PjBL), Creativity, Science Learning.

\begin{abstract}
Abstrak. Tujuan penelitian ini adalah untuk mendeskripsikan kreativitas mahasiswa melalui pembelajaran Project Based Learning. Penelitian dilakukan dengan desain One-Shot Case Study dengan subjek penelitian 45 mahasiswa program pendidikan guru sekolah dasar FKIP Universitas Bung Hatta. Data penelitian diperoleh dari analisis lembar observasi produk dengan skala berpikir kreatif (Creative Thinking Scale / CTS). Analisis data dengan teknik persentase dan diolah secara deskriptif. Hasil penelitian menunjukkan kreativitas mahasiswa dalam menghasilkan produk kerajinan olahan limbah organic dan anorganik sangat tinggi dengan nilai 92. Dapat disimpulkan bahwa model pembelajaran Project Based Learning dapat meningkatkan kreativitas mahasiswa.
\end{abstract}

Kata kunci: Model PjBL(PjBL), kreativitas, pembelajaran IPA

\section{Pendahuluan}

Pendidikan merupakan proses pembelajaran berupa kegiatan belajar mengajar, dimana terjadinya interaksi antara siswa dan guru. Dalam bidang pendidikan guru berperan sebagai tenaga pendidik yang membimbing siswa untuk mampu mengembangkan ilmu pengetahuan dan dapat merubah kondisi siswa dari yang tidak tahu menjadi tahu (Sari, 2017:23). Pendidikan dipandang sebagai salah satu faktor utama yang menentukan pertumbuhan ekonomi, yaitu melalui peningkatan produktivitas tenaga kerja terdidik, dan juga pendidikan dipandang mempunyai peranan penting dalam menjamin perkembangan dan kelangsungan bangsa (Sari, 2016:161) Kualitas pendidikan dapat diketahui dari dua hal, yaitu kualitas proses dan produk. Pendidikan dikatakan berkualitas apabila terjadi penyelenggaraan pembelajaran yang efektifdan efisien dengan melibatkan semua komponen-komponen pendidikan, seperti mencakup tujuan pengajaran, guru dan peserta didik, bahan pelajaran, strategi atau metode belajar mengajar, 
alat dan sumber pelajaran serta evaluasi (Sari, 2017:27). Keberhasilan penyelenggaraan pendidikan dapat dipengaruhi oleh beberapa faktor salah satunya adalah kesiapan guru dalam mempersiapkan peserta didik melalui proses pembelajaran.

Pada hakekatnya penyampaian materi pembelajaran atau proses belajar mengajar merupakan proses komunikasi yaitu proses penyampaian pesan atau pikiran dari seseorang kepada orang lain, penggunaan metode yang tepat akan menjadikan siswa secara efektif mampu menerima pesan yang disampaikan (Sari, 2018:16). Berdasarkan Undang-Undang No.20 Tahun 2003 jelaslah bahwa tugas seorang guru tidak hanya menyampaikan ilmu saja tetapi masih banyak yang harus dilakukan guru yaitu mendidik siswa agar menjadi manusia yang utuh, dengan demikian dapat dikatakan bahwa tugas guru lebih berat. Seorang guru dituntut penguasaan berbagai kemampuan sebagai guru yang profesional dalam bidangnya (Sari, 2016:161). Kemampuan yang dimaksud dimulai dari cara mengajar, penguasaan materi, pemilihan berbagai metode mengajar, kemampuan membuat perangkat/ media mengajar, sikap, tauladan dan lain sebagainya.

Seorang guru hendaknya memahami perannya agar dalam menyampaikan materi dapat mencapai tujuan pembelajaran yang diharapkan. Menurut Rusman (2012:22), dalam memahami perannya guru hendaknya memiliki 4 kompetensi dasar pendidik meliputi, 1) Kompetensi Pedagogik, adalah kemampuan mengelola pembelajaran peserta didik yang meliputi pemahaman terhadap peserta didik, perancangan dan pelaksanaan pembelajaran. 2) Kompetensi Personal, adalah kemampuan kepribadian yang mantap, stabil, dewasa, arif, dan berwibawa, menjadi tekladan bagi peserta didik, dan berakhlak mulia. 3) Kompetensi Profesional, adalah kemampuan penguasaan materi pembelajaran secara luas dan mendalam yang memungkinkan, membimbing peserta didik memenuhi standar kompetensi. 4) Kompetensi Sosial, adalah kemampuan guru sebagai bagian dari mayarakat untuk berkomunikasi dan bergaul secara efektif dengan peserta didik, sesama pendidik, wali murid, dan masyarakat sekitar.

Pendidikan tidak terlepas dari kurikulum yang telah dirancang, disusun dan ditetapkan oleh pemerintah yang berpengaruh terhadap kualitas pendidikan sebuah negara. Mengacu pada Kurikulum Tingkat Satuan Pendidikan (KTSP) tahun 2006, diketahui bahwa Ilmu Pengetahuan Alam (IPA) berhubungan dengan cara mencari tahu tentang alam secara sistematis, sehingga IPA bukan hanya penguasaan kumpulan pengetahuan yang berupa fakta-fakta, konsep-konsep, atau prinsip-prinsip tetapi juga merupakan suatu proses penemuan. Oleh karena itu, dalam proses pembelajaran IPA siswa diberi kesempatan untuk menemukan kebenaran suatu fakta atau konsep dari materi yang dipelajarinya melalui percobaaan-percobaan, sehingga siswa memiliki keterampilan untuk mengamati, menganalisis, membuktikan dan menarik kesimpulan dari suatu objek serta menuliskan keadaan atau suatu proses yang diam (Sari, 2017:29).

Oleh karena itu, guru harus mampu menciptakan suasana belajar yang kondusif, dan menyenangkan bagi siswa agar tujuan pembelajaran dapat tercapai dengan semestinya. Menyikapi kenyataan tersebut, guru dituntut untuk melakukan pembenahan dan praktik pembelajaran di kelas, salah satunya dengan menggunakan model Project Based Learning (PjBL). Project Based Learning ialah "Proses pembelajaran yang secara langsung melibatkan siswa untuk menghasilkan suatu proyek. Pada dasarnya model pembelajaran ini lebih mengembangkan keterampilan memecahkan dalam mengerjakan sebuah proyek yang dapat menghasilkan sesuatu. Dalam implementasinya, model ini memberikan peluang yang luas kepada siswa untuk membuat keputusan dalam memilih topik, melakukan penelitian, dan menyelesaikan sebuah proyek tertentu. Pembelajaran dengan menggunakan proyek sebagai metoda 
pembelajaran. Para siswa bekerja secara nyata, seolah-olah ada didunia nyata yang dapat menghasilkan produk secara realistis.

Berdasarkan latar belakang di atas, maka rumusan masalah yang dikemukakan adalah "bagaimanakah kreativitas mahasiswa melalui penerapan model Project Based Learning?. Adapun tujuan penelitian untuk mendeskripsikan kreativitas mahasiswa melalui penerapan model Project Based Learning.

\section{Metode}

Desain penelitian ini adalah desain eksperimen One-Shot Case Study (Sugiyono, 2008:78). Subjek penelitian adalah mahasiswa Program Studi Pendidikan Guru Sekolah Dasar (PGSD) pada mata kuliah Konsep Dasar IPA 1 yang berjumlah 45 mahasiswa. Proses pembelajaran menekankan pada pembelajaran berbasis proyek untuk membuat produk kerajinan etnobotani minangkabau dari olahan limbah organic dan anorganik. Hasil karya mahasiswa di observasi sebagai hasil kemampuan berpikir kreatif dalam pengolahan limbah organic dan anorganik menjadi kerajinan.

Instrument yang digunakan dalam penelitian ini adalah lembar observasi produk. Data yang diobervasi berupa skala berpikir kreatif (Creative Thinking Scale / CTS) sebagai penilaian proses desain kreatif dari sebuah proyek. Data yang diperoleh dianalis dengan menggunakan rumus persentase yang dikemukakan Sari (2012:63).

$$
\begin{aligned}
& \text { Keterangan: } \\
& \mathrm{Na}=\text { Nilai afektif } \\
& \mathrm{X}=\text { Skor yang diperoleh } \\
& \mathrm{Xm}=\text { Skor maximum }
\end{aligned}
$$

Kriteria penilaian kreativitaas diadopsi dan dimodifikasi dari Sari (2012:63)seperti Tabel 1.

Tabel 1. Kriteria Kreatifitas Mahasiswa

\begin{tabular}{cl}
\hline$\%$ & \multicolumn{1}{c}{ Kriteria Kreatifitas } \\
\hline $81-100$ & Sangat tinggi \\
$61-80$ & Tinggi \\
$41-60$ & Sedang \\
$21-40$ & Rendah \\
$1-20$ & Sangat rendah \\
\hline
\end{tabular}

\section{Hasil dan Pembahasan}

\section{Hasil}

Kreatifitas mahasiswa dalam mengolah limbah organic dan anorganik menjadi kerajinan melalui pembelajaran Project Based Learning menunjukkan produk-produk kerajinan yang diharapkan. Penilaian produk-produk kerajinan olahan limbah organic dan anorganik di nilai dengan skala berpikir kreatif (Creative Thinking Scale / CTS). Rata-rata kreatifitas mahasiswa dalam mengolah limbah organic dan anorganik dapat dilihat pada Tabel 2.

Tabel 2. Rata-rata kreatifitas mahasiswa matakuliah Konsep Dasar IPA I dalam mengolah limbah organik dan anorganik

\begin{tabular}{cccc}
\hline No & aspek yang diamati & skor rata-rata & Kategori \\
\hline 1 & Perencanaan & 93.75 & Sangat Tinggi \\
2 & Pelaksanaan & 93.75 & Sangat Tinggi \\
3 & Laporan & 87.5 & Tinggi \\
\hline Rata-rata persentase & & 92 & Sangat Tinggi \\
\hline
\end{tabular}


Pada Tabel 2 dapat diketahui kreatifitas mahasiswa melalui pembelajaran $P j B L$ berada pada kategori sangat tinggi dengan rata-rata 92. Kategori tinggi ditunjukan pada aspek laporan dengan rata-rata 87,5. Indicator penilaian aspek laporan yaitu performa dan kesesuaian produk yang dihasilkan. Sementara itu, aspek perencanaan memiliki rata-rata sangat tinggi dengan rata-rata 93,75. Indikator penilian pada aspek perencanaan adalah persiapan alat dan bahan serta gambar kerja. Aspek pelaksanaan memiliki rata-rata 93,75 dengan kategori sangat tinggi. Indicator yang dinilai pada aspek pelaksanaan ini adalah sikap kerja, penggunaan alat, bahan, pengerjaan, perakitan dan finishing. Dari hasil penilaian observasi produk dengan skala berpikir kreatif (Creative Thinking Scale / CTS) mahasiswa sangat tinggi. Hal ini mengindikasikan bahwa model pembelajaran PjBL dapat meningkatkan kreatifitas mahasiswa. Kreatifitas mahasiswa melalui pembelajaran $P j B L$ dalam pengolahan limbah organic dan anorganik lebih terarah dan jelas.

\section{Pembahasan}

Berdasarkan hasil penilaian produk kerajinan yang dihasilkan 45 mahasiswa PGSD pada matakuliah Konsep dasar IPA I, menunjukkan kreativitas mahasiswa dalam menghasilkan produk kerajinan olahan limbah organic dan anorganik sangat tinggi dengan nilai 92. Tirtiana (2013:17) menyatakan bahawa kreativitas merupakan kemampuan mengimajinasikan, menafsirkan dan mengemukakan gagasan serta usaha yang memiliki daya cipta untuk kombinasi baru dari unsur sebelumnya yang sudah ada sehingga diperoleh peningkatan kualitas siswa dalam pengembangan dirinya. Hal ini sejalan dengan Saefudin (2012:41) kreativitas merupakan suatuproduk kemampuan(berpikir kreatif) untuk menghasilkan suatu cara atau sesuatu yang baru dalam menghadapi suatu masalah atau situasi.

Dalam menghasilkan produk-produk kerajinan dari limbah organic dan anorganik mahasiswa dituntut untuk berpikir kreatif terhadap produk yang didesain. Berpikir kreatif diartikan sebagai suatu kegiatan mental yang digunakan seseorang untuk membangun ide atau gagasan baru (Suarsana, 2013:273). Hal ini sejalan menurut Saefudin (2012:40) bahwa berpikir kreatif melibatkan logika dan intuisi secara bersama-sama. Secara khusus dapat dikatakan berpikir kreatif sebagai satu kesatuan atau kombinasi dari berpikir logis dan berpikir divergen guna menghasilkan sesuatu yang baru. Sesuatu yang baru tersebut merupakan salah satu indikasi berpikir kreatif dalam IPA, sedangkan indikasi yang lain berkaitan dengan berpikir logis dan berpikir divergen. Saefudin (2014:43) menyatakan bahwa berpikir kreatif sebagai kombinasi dari berpikir logis dan berpikir divergen yang berdasarkan pada intuisi dalam kesadaran. Oleh karena itu, berpikir kreatif melibatkan logika dan intuisi secara bersama-sama. Secara khusus dapat dikatakan berpikir kreatif sebagai satu kesatuan atau kombinasi dari berpikir logis dan berpikir divergen guna menghasilkan sesuatu atau produk yang baru (Rahayu, 2011:107).

Melalui model pembelajaran $P j B L$ mahasiswa dapat meningkatkan kreatifitas dalam berkarya. Produk kerajinan yang dihasilkan sangatlah memiliki nilai ekonomi yang tinggi. Memberi peluang bagi mahasiswa dalam menciptakan jiwa interpreneur (wirausaha). Sehingga dengan kata lain, model pembelajaran $P j B L$ adalah model pembelajaran yang membutuhkan keterampilan dengan menggunakan prinsip belajar sambil mengerjakan (learning by doing). Hal ini sejalan menurut Saefudin (2014:43) menyatakan bahwa PjBL memberikan kesempatan pembelajar untuk meneliti, merencanakan, mendesain dan refleksi terhadap pembuatan proyek teknologi. Selain itu Tirtiana (2013:22) mengemukakan bahwa model PjBL dapat meningkatkan kreativitas belajar siswa SMK 2 Blora. Wusqo (2014:78) berpikir kreatif dalam suatu $P j B L$ tidak hanya membutuhkan perubahan metode mengajar dan suasana pembelajaran, tetapi juga harus mengadopsi metode asessmen baru seperti portofolio yang berdasarkan aktivitas 
mahasiswa. Portofolio akan merefleksikan apa yang sudah dipelajari oleh mahasiswa bagaimana cara mengajukan pertanyaan, menganalisis, mensitesis, mengatasi masalah dengan cara membuat ide baru, dan kemudian mendesain dan membuat suatu produk inovatif yang baru. Portofolio juga menampilkan bagaimana mahasiswa berinteraksi secara intelektual, emosional dan social dengan rekan kerjanya.

\section{Kesimpulan}

Dari hasil penelitian yang telah dilakukan dapat disimpulkan bahwa kreativitas mahasiswa dalam menghasilkan produk kerajinan olahan limbah organik dan anorganik sangat tinggi dengan nilai 92 sehingga dapat disimpulkan bahwa model pembelajaran $P j B L$ mampu meningkatkan kreativitas mahasiswa.

\section{Daftar Pustaka}

Rahayu. (2011). Pembelajaran Sains dengan Pendekatan Keterampilan Proses untuk Meningkatkan Hasil Belajar dan Kemampuan Berpikir Kreatif Siswa. Jurnal Pendidikan Fisika Indonesia 7 (2011) : 106-110.

Rusman. (2012). Seri Manajemen Sekolah Bermutu, Model-Model Pembelajaran: Mengembangkan Profesionalisme Guru. Jakarta: Rajawali Pers.

Saefudin.A.A. (2012). Pengembangan Kemampuan Berpikir KreatifSiswa Dalam Pembelajaran Matematika Dengan Pendekatan Pendidikan Matematika Realistik Indonesia (PMRI). AlBidāyah, Vol 4 No. 1, Juni 2012: 37-48.

Sari, R.T. (2012). Pengembangan Perangkat Pembelajaran Berorientasi Pendidikan Karakter dalam Pembelajaran IPA SMK. Tesis. Universitas Negeri Padang.

Sari, R. T. (2016). Analisis Perencanaan Pembelajaran IPA pada Materi Ekosistem Kelas XII SMK Negeri 4 Padang. Varia Pendidikan Kajian Penelitian Pendidikan. Vol 28, No 2 Desember 2016. ISSN 0852-0976:160-168.

Sari, R. T. (2017). Uji Validitas Modul Pembelajaran Biologi Pada Materi Sistem Reproduksi Manusia Melalui Pendekatan Konstruktivisme Untuk Kelas IX SMP. Scientiae Educatia: Jurnal Pendidikan Sains, 6(1), 22-26.

Sari, R. T., \& Jusar, I. R. (2017). Analisis Kebutuhan Modul Pembelajaran IPA Berorientasi Pendidikan Karakter Melalui Pendekatan Quantum Learning di Sekolah Dasar. Bioedukasi (Jurnal Pendidikan Biologi), 8(1), 26-32.

Sari, R. T., \& Jusar, I. R. (2018). Analysis of Science Learning Process by Using Learning Module of Character Education Oriented through Quantum Learning Approach. Jurnal Penelitian dan Pembelajaran IPA, 4(1), 14-24.

Sugiyono. (2008). Metode Penelitian Pendidikan Pendekatan Kuantitatif, Kualitatif dan $R \& D$. Bandung: Alfabeta.

Suarsana. M.I dan G.A. Mahayukti. (2013). Pengembangan E-Modul Berorientasi Pemecahan Masalah Untuk Meningkatkan Keterampilan Berpikir Kritis Mahasiswa. Jurnal Pendidikan Indonesia. Vol. 2, No. 2, Oktober 2013: 264-275.

Tirtiana. P. C. (2013). Pengaruh kreativitas belajar, penggunaan media Pembelajaran power point, dan lingkungan keluarga terhadap hasil belajar mata pelajaran akuntansi pada siswa kelas x akt smk negeri 2 blora tahun ajaran 2012/2013 (motivasi belajar sebagai variabel intervening). EEAJ 2 (2) (2013) : 15-23

Wusqo. I.U. (2014). Upaya mendorong kemampuan berfikir Kreatif mahasiswa dalam inovasi konservasi pangan. Indonesian Journal of Conservation. Vol. 3 No. 1 - Juni 2014 [ISSN: 2252-9195]: $75-82$. 